\author{
St udia Philosophic a \\ Wr a t i s l a vi e n s i a \\ vol. XIV, fasc. 1 (2019) \\ DOI: $10.19195 / 1895-8001.14 .1 .4$
}

\author{
ADAM CHMIELEWSKI \\ ORCID: 0000-0001-6001-5309 \\ University of Wrocław
}

\title{
Two Concepts of Recognition
}

\begin{abstract}
The aim of this paper is to submit the doctrine of methodological individualism to a reconsideration from the point of view of the arguments formulated by contemporary communitarian philosophy. I propose to approach the opposition between the individual and the community, constitutive for the liberal-communitarian debate, by means of two concepts, i.e. those of recognition and order. I argue that for the individualists a social order emerges through a process of mutual recognition of the pre-existing individuals and their interests, while the communitarians claim that the task of individuals is to recognize values and norms of a pre-existing social order which is to become their own. The difference between them thus resides primarily in the ontological distinction between the respective objects of these two divergent concepts of recognition. The argument is developed through an analysis of David Hume's concept of the individual. In opposition to some communitarian claims, I maintain that his approach may be interpreted as an antecedent of the communitarian views on the subject. I also outline a view of moral rules as neither universal, absolutist, nor purely emotivist in character, but as social constructions endowed with the status of "contingent permanence."
\end{abstract}

Keywords: methodological individualism, recognition, Hume's concept of the individual

\section{Social Atomism}

The Western understanding of the nature of society is essentially individualistic. We tend to perceive the society as a cluster of independent and autonomous atomic entities, each moving on an idiosyncratic trajectory, determined by the irreducibly individual dispositions, beliefs, unique features and sovereign decisions. Such a vision of society dominates in all our pursuits, both practical and intellec- 
tual. Most of us seem to assume it instinctively in our defences of our inalienable rights, of our freedom of choice, and the freedom to pursue our private happiness and private life-plans formulated in accordance with our own conceptions of the good. In general, we adopt such a view of society, and of ourselves, as a natural, or indeed an original position. Such an approach to society and the individual is grounded in a conception known as the methodological individualism.

The concept of the individual began to play a robust explanatory role within the intellectual order established by the Renaissance philosophy, i.e., the intellectual regime within which the concept of the individual has come to play the role of a nodal point. It continued to exert its unquestioned power until recently when it was challenged by the champions of the moral and political philosophy of communitarianism. I would like to argue that methodological individualism is not an innocent philosophical position. It is usually adopted as a preliminary step in attempts toward a solution of many other, much more important and more practically relevant issues, solutions which are far from uncontroversial. Methodological individualism provides a conceptual grounding for individualistic doctrines, especially in moral and political philosophy.

The principle of methodological individualism has been most clearly formulated and explained by John Watkins in a series of papers devoted to the problems of explanation in social and historical sciences. He wrote:

According to the [principle of] mechanism, the ultimate constituents of the physical world are impenetrable particles which obey simple mechanical laws. The existence of these particles cannot be explained - at any rate by science. On the other hand, every complex physical thing is the result of a particular configuration of particles and can be explained in terms of the laws governing their behaviour in conjunction with a description of their relative positions, masses, moments etc. [...] I am not an advocate of mechanism, but [...] I am an advocate of an analogous principle in social science, the principle of methodological individualism. According to this principle, the ultimate constituents of the social world are individual people who act more or less appropriately in the light of their dispositions and understanding of their situation. Every complex situation, institution, or event is the result of a particular configuration of individuals, their dispositions, situations, beliefs and physical resources and environment. ${ }^{1}$

Watkins saw his own individualistic position as opposed to the doctrine of holism or organicism, according to which "social systems constitute 'wholes' at least in the sense that some of their large-scale behaviour is governed by macro-laws which are essentially sociological in the sense that they are sui generis and not to be explained as mere regularities or tendencies resulting from the behaviour of interacting individuals." And, he adds, "If methodological individualism means that human beings are supposed to be the only moving agents in history, and if sociological holism means that some superhuman agents or factors are supposed to be at work in history, then these two alternatives are exhaustive."2

The opposition drawn by Watkins is a convenient way to view a number of problems and oppositions which have been dividing thinkers in moral and political

\footnotetext{
1 J.W.N. Watkins, "Historical Explanations in the Social Sciences," The British Journal for the Philosophy of Science 8 (1957), p. 106.

2 Ibid.
} 
philosophy for centuries. There are those, then, who, in a very much similar vein, wish to uphold the picture of a person as a fully autonomous atom of the society and attribute the priority to thus monadically conceived individual. There are also those who follow Aristotle in his conviction that "The whole is necessarily prior to the part. If the whole body is destroyed, there will be not a foot or a head", from which he concluded that "the polis exists by nature and that it is prior to the individual."3 Questioning especially the autonomy of the individual reason, those thinkers seem to be "afraid to put men to live and trade each on his own stock of reason; because [they] suspect that this stock in each man is small and that individuals would do better to avail themselves of the general bank and capital of natures and of ages." Accordingly, they emphasize the priority of the community and understand it as the primary source of determinations responsible for the social construction of the individual who does not possess an independent existence apart from the community. More importantly still, they perceive the atomistic vision of society as a threat to the ethnocentric identities and differences by means of which they try to define the meaning and purpose of individual lives. They reject, in some cases vehemently, this concept of society and of the individual, and criticise the view of community as constituted only by the impoverished relationships reduced to the contractual ties. They also strive to return to the natural thick fabric of social bonds which is being upset by the excesses of - to use C.B. Macpherson's phrase - possessive liberal individualism. ${ }^{5}$

A major problem affecting the atomist position has to do with the fact that the concept of autonomous human individuals, which plays within it the role of a nodal point, does help to solve some philosophically interesting questions, but also, more importantly, it prevents one from asking other, no less interesting ones. ${ }^{6}$ For it seems that individualism, just because it sees human beings as "irreducible" and final constituents of the society, prevents itself from considering the questions of the utmost philosophical importance, namely the issue of the constitution of human self and of the sources of its rationality, autonomy and freedom. By ascribing the fundamental and final status to the human self, it turns a blind eye to a vast philosophical domain of the ways and modes in which numerous factors do take part in shaping individuals into their idiosyncratic forms; in doing so, it significantly impoverishes its own cognitive perspective.

From a communitarian point of view, on the one hand, liberal doctrines are vulnerable because they perceive the atomist conception of the individual as fundamentally flawed. On the other, however, liberals reject the communitarian contextual and holistic approach to the individual because they think it undermines human agency and freedom. In other words, what liberals see as attraction in the social atomism, is seen by the communitarians as a liability. It seems indeed as if

\footnotetext{
${ }^{3}$ Aristotle, Politics, transl. E. Barker, Oxford 1948, 1253a, pp. 7-8.

${ }^{4}$ E. Burke, Select Works of Edmund Burke, vol. 2, Indianapolis 1999, p. 142.

${ }^{5}$ C.B. Macpherson, The Political Theory of Possessive Individualism: Hobbes to Locke, Oxford-New York 1962 .

${ }^{6}$ Ch. Taylor, "What is Wrong with Negative Liberty," [in:] Ch. Taylor, Philoshophy and the Human Sciences: Philosophical Papers, vol. 2, Cambridge 1985, p. 215.
} 
the participants of the debate talk at cross-purposes. Thus, if there is any hope of overcoming this perennial debate, it will have to be sought through the comprehensive criticism of the concept of the individual persistent in our culture.

The individualist philosophy has been usually traced to the intellectual efforts of the pre-Enlightenment and Enlightenment thinkers whose work was crucial in defining the modern philosophical and moral ideals of the liberal and democratic society. It thus seems worthwhile to consider to what extent the charges levelled against the Enlightenment as responsible for the modern era's individualist culture are justified.

A justification for this historical assertion may be found, for example, in John Locke, the 18th-century proponent of the contractual political theory, who developed his account of the political society in a decidedly individualist fashion. In the Second Treatise of Government he wrote that

Men being, as has been said, by nature, all free, equal, and independent, no one can be put out of this estate, and subjected to the political power of another, without his own consent. The only way whereby any one divests himself of his natural liberty, and puts on the bonds of civil society, is by agreeing with other men to join and unite into a community for their comfortable, safe, and peaceable living one amongst another, in a secure enjoyment of their properties, and a greater security against any, that are not of it. ${ }^{7}$

Locke's political theory is based on the idea of natural human rights and was employed by him to contest the religiously inspired traditional political authoritarianism, especially in the form given to it by a religious thinker Robert Filmer in his work Patriarch (1680). The basic philosophical assumption in Locke's conception seems to be a conviction that individual membership in political associations can be essentially reduced to its instrumental value, that of protecting personal freedoms of individuals, and, most importantly for Locke, their property. For, as he wrote, "The great and chief end, therefore, of men's uniting into common-wealths, and putting themselves under government, is the preservation of their property."

This individualistic idea of society is further strengthened by the writings of other Enlightenment writers, British and European alike. Adam Smith's moral theory, for example, even though its crucial concepts, that of sympathy and of the impartial spectator within one's breast, are construed as fundamentally social ones, ${ }^{9}$ does not differ much from Locke's individualism. In particular, the social dimension of his crucial moral concepts does not prevent Smith from describing the

7 J. Locke, Second Treatise of Government, C.B. Macpherson (ed.), Indianapolis 1980, par. 95, p. 52.

8 Ibid., par. 124 , p. 66.

9 "As we have no immediate experience of what other men feel, we can form no idea of the manner in which they are affected, but by conceiving what we ourselves should feel in the like situation" (A. Smith, The Theory of Moral Sentiments, D.D. Raphael, A.L. MacFie (eds.), Indianapolis 1982, p. 9). Also: "Man of the most robust make, observe that in looking upon sore eyes they often feel a very sensible soreness in their own" (Ibid., p. 10). The concept of sympathy in Smith cannot be equated with that of benevolence, as some commentators have interpreted it, and inferred from this confusion that in the Theory of Moral Sentiments he dealt with the altruistic side of human conduct, whereas in the Wealth of Nations with its egoistic side. The editors of the quoted edition assert that such an interpretation of Smith's work is mistaken (Ibid., "Introduction," sect. 2(b)). 
ideal of the prudent man, with which he evidently sympathises, in the following manner:

The prudent man is not willing to subject himself to any responsibility which his duty does not impose upon him. He is not a bustler in business where he has no concern; is not a meddler in other people's affairs; is not a professed counsellor or adviser, who obtrudes his advice where nobody is asking it. He confines himself, as much as his duty will permit, to his own affairs and has no taste for that foolish importance which many people wish to derive from appearing to have some influence in the management of those of other people. He is averse to enter into any party disputes, hates faction, and is not always very forward to listen to the voice even of noble and great ambition. When distinctly called upon, he will not decline service of his country, but he will not cabal in order to force himself into it, and would be much better pleased that the public business were well managed by some other person, than that he himself should have the trouble, and incur the responsibility, of managing it. ${ }^{10}$

Smith's idea of the prudent man is not dissimilar from the idea of the magnanimous man described in the Aristotle's Nicomachean Ethics, a rational, self-composed, self-commanding, well-mannered, independent, well-off person, moderate in his emotions, who thinks of himself as justly deserving greatest things and receiving them. The idea of the self-centred individual, devoid of any deep interest in the fate of others, incapable of emotional commitment or devout love, does not leave much space for the social feelings and interests apart of those directly related to one's own business. Thus, the charges of the egoistic individualism, so often levelled against the thinkers of the Enlightenment, fit Smith quite well.

The individualist morality, although it has been formulated predominantly by the English-speaking Enlightenment philosophers and had been a position most common among them, is not limited to the Anglo-Saxon soil. The picture of social ties and social virtues emerging from the Kant's moral philosophy can be summarised as a kind of Leibnizian harmony of moral monads, organising themselves into associations that enhance and preserve rather that threaten the individual sphere and freedom of each. For Kant

The tightest possible association between persons will be by life-long contract within marriage (a form avoided by Kant) or friendship tied by vows of friendship, the rest will be the quasi-contractual ties of fellow citizens under a common magistrate and a common law, and the loosest but not unimportant tie is that of cosmopolitan sentiment linking all mutually respectful autonomous persons in practices of "affability, sociability, courtesy, hospitality, and gentleness (in disagreeing without quarrelling)." Presumably, these cosmopolitan sentiments are to be largely reserved for those who are citizens of nations with whom our own nation is not currently at war, since Kant takes perpetual peace to be more an idea or ideal of practical reason than a realistic expectation. ${ }^{11}$

The situation is considerably different in the case of Jean-Jacques Rousseau who is usually held responsible for the French authoritarianism and anti-individualism and the persistent French negative attitude toward liberalism; his idea of the social contract strikingly departs from the one developed by British authors. Yet, as it was stressed, Rousseau's authoritarian ideas were just an alternative restatement of arguments which before him were employed, especially by

${ }^{10}$ Ibid., pp. 215-216.

11 A. Baier, "How Can Individualists Share Responsibility?," [in:] A. Baier, Moral Prejudices: Essays on Ethics, Cambridge-London 1994, p. 248. 
Thomas Hobbes, in support of the conception of power incarnated in the absolute monarchy. In particular, his concept of the general will, according to which the sovereignty cannot be divided nor restricted, conjoined with the idea of the total alienation of the rights of each individual entering the social contract which form his idea of the radically democratic popular sovereignty, can be seen as a reversal of the claims about the absolutist monarchical sovereignty.

Rousseau's contract is in one sense anything but contractual. Postulated is a pact between a collectivity considered as a single moral person and each of its members taken individually. From this it follows that of the two contracting parties it is only one-the individuals concerned-who could be in breach of the agreement entered into. By an altogether different route we arrive therefore at a conclusion that at one level is similar to that of Hobbes: the social contract gives "absolute power" to the sovereign over his subjects. If this is so it is in part because Rousseau, unlike for example Locke, did not view the foundational contract as a means of regulating the required balance between rights bearing individuals and government or of securing the liberal functioning of institutions. For him, as for Hobbes, the contract was constitutive of society itself. Where, however, Rousseau diverged from Hobbes was in the ends envisaged. For Hobbes it was civil peace and commodious living, for Rousseau it was ensuring that men could unite without giving up any of their liberty and the moral improvement of the constituent parts of civil society. ${ }^{12}$

But even his seemingly anti-individualist idea of social contract has been interpreted by some of Rousseau's followers as one in which the individual "will remain sovereign, and the society will be legitimate, if, social power having been given over to the whole, there is an identity of interests and of views between each person and the community, between the sovereign as everyone and the sovereign as individual." 13

In John Rawls's account of the social justice the individualistic approach functions on the explanatory as well as on the moral and political levels. His intentions in writing $A$ Theory of Justice were

to present a conception of justice which generalises and carries to a higher level of abstraction the familiar theory of the social contract as found in Locke, Rousseau and Kant. [...] The guiding idea is that the principles of justice for the basic structure of society are the object of the original agreement. They are principles that free and rational persons concerned to further their own interests would accept in an initial position of equality and in defining the fundamental terms of society. ${ }^{14}$

For, as a rule, the individualists, or social atomists believe that the principle of methodological individualism is to be employed not only in the explanation of social phenomena, but that it has also to be adopted as a basis for any account of the nature of social goods. For the atomists those goods are, ultimately, concatenations of individual goods. This tradition of thought, which includes thinkers like Alexis de Tocqueville, John Stuart Mill, Wilhelm von Humboldt, Isaiah Berlin, Karl Popper, has found its natural ally in yet another English defender of the liberal individualistic conception of society, Margaret Thatcher, known for her claim that there is no such thing as society, there are only individuals.

12 J. Jennings, "Rousseau, Social Contract and the Modern Leviathan," [in:] The Social Contract from Hobbes to Rawls, D. Boucher, P. Kelly (eds.), London-New York 1994, p. 120.

13 P. Leroux, "Aux Politiques," [in:] P. Leroux, Ouvres, vol. 1, Paris 1850, p. 154.

14 J. Rawls, A Theory of Justice, Oxford 1971, p. 11. 


\section{Two Concepts of Recognition}

The controversy between liberals and communitarians has been usually discussed through the lenses of the opposition between the individual and the community, the man and the society. One may express this opposition also by employing the concepts of recognition and order. Thus, within the individualist approach, the social order is established as a result of the prior mutual recognition of the pre-existing individual human beings and their particular interests. The social order thus established is being informed, and undergoes continuous transformations, in the course of the struggle for recognition between individuals and their groups. The purpose of the ongoing struggle for recognition is to secure goods of self-confidence, self-respect, and self-esteem, necessary for the self-realisation of each individual. In opposition to this, the communitarian approach may be interpreted as implying the concept of recognition not only as pertaining to the mutual relationships between individuals or their groupings, but also as pertaining to the relationships between individuals (or their groupings) and norms constitutive for a pre-existing social order. Therefore, for the communitarians, the concept of recognition effectively functions as an explanatory principle not only for the dynamics of the relationships between the individuals or their groupings. It serves also to explain the relationships between individuals or their groupings and abstract values embodied in a form of life in which they live. Accordingly, one may claim that within the communitarian perspective, the individuals are to win not only the self-confidence, self-respect and self-esteem in the sense outlined by Axel Honneth, but also, furthermore, they are to recognize as normatively binding the values and norms constitutive for the social order they inhabit. Moreover, and more importantly, within the communitarian approach, the recognition in the second above-delineated sense performs a regulatory function for the struggle for recognition in the first sense, i.e., they perform the role of a "discipliner or denier of human feeling-guided will," 15 which fuels the struggle for recognition. For the values and norms, which are the objects of recognition in the second sense, inform and pervade the modes of the struggle for recognition going on between both individuals within a given community, as well as between it and other communities. ${ }^{16}$ The regulatory function of those impersonal values and norms, subject of recognition in the second sense, is, as a rule, overlooked or rejected by the individualist approach; from its point of view, the goods striven for through the struggle for recognition are not to be imposed from above by a normative system of values, but are constituted by individual needs and desires. In other words, one may say that while both concepts, those of order and recognition, remain crucial for both for the individualist and communitarian approaches, they differ due to their divergent conceptions of the origin of social order, as well as due to the ontological difference between the objects of recognition they respectively adopt.

${ }^{15}$ A. Baier, Postures of the Mind: Essays on Mind and Morals, Minneapolis 1985, p. 249.

16 A. Honneth, The Struggle for Recognition: Moral Grammar of Social Conflicts, transl. J. Anderson, Cambridge 1995, p. 89. 
It has to be stressed that majority of the theorist of recognition understand recognition as characteristic of the relationships between the individuals, groups of individuals or institutions, while few, if any, allow for a possibility of recognition characterising the relationship between individuals or groups of individuals and abstract objects like moral values. For this reason, the discourse of recognition usually addresses the psychological, social and political phenomena, while a given system of moral values, as well the value of the individuals themselves, is usually seen as constituted and established in the process of the struggle of recognition itself only. What is being usually disregarded is the possibility of recognition taking place between the individuals or their groupings and the abstract values embodied in a form of life they inhabit. It has to be stressed that Honneth's approach allows him to see moral values and norms, i.e., "abstract horizon of ethical values,"17 as generated by various forms of the struggle for recognition between individuals, and he stresses that "the formal concept of the good life or, indeed, of ethical life [sittlichkeit]"18 performs the function of normatively informing all forms of struggle for self-realization by individuals, yet he does not address the problem of how the contingently established norms and values are capable of performing their regulatory function. It is thus worthwhile to see how the communitarian-leaning thinkers conceptualize the regulatory function of the normative systems.

\section{The Communitarian Challenge}

Watkins asserts that the existence of social elementary particles cannot be explained. What the non-individualists try to do is precisely to explain the nature of these particles, to show how they come into being and how they are shaped into various and distinct forms which usually escape the notice of the atomist. In other words, they want to penetrate that which has been assumed by the individualists as impenetrable.

One of the most outspoken critics of the Enlightenment individualist tradition, Alasdair MacIntyre, takes this concept of an individual as a chief aim of his criticism. He claims that the "I" for an individualist seems to be just a peg on which to hang anything one wishes to. Such a self has no history, no sources, no origin. Such a metaphysical view of the self, adopted out fear of relativism, historicism and constructivism, enables the individualists to avoid answering the question where does the individual come from. In doing so, however, they turn their blind eye on the complex issues of social construction of the human self, and eventually adopt various versions of moral voluntarism and emotivism. MacIntyre describes the individualist views of the self in the following manner:

From the standpoint of individualism I am what I myself choose to be. I can always, if I wish to, put in question what are taken to be the merely contingent social features of my existence. I may biologically be my father's son; but I cannot be held responsible for what he did unless I choose implicitly

$\begin{array}{ll}17 & \text { Ibid., p. } 179 . \\ 18 & \text { Ibid., p. } 171 .\end{array}$

Studia Philosophica Wratislaviensia 14, 2019 z. 1,

(C) for this edition by CNS 
or explicitly to assume such responsibility. I may legally be a citizen of a certain country; but I cannot be held responsible for what my country does or had done unless I choose implicitly or explicitly to assume such responsibility. ${ }^{19}$

From the perspective of the communitarian philosophy, the crucial problem which liberal individualists cannot answer is how an individual acquires his or her ability to wish, to act, to choose, to consider, to assume responsibility, in the first place. MacIntyre proposes the narrative concept of the self, according to which the helpless and dependent creatures which initially resemble human beings only in virtue of their bodily shape, are becoming fully human through listening, learning and imbibing the moral lessons stemming from the array of narratives told and retold by his community throughout its history. One becomes human through the participation in the narratives of a community; furthermore, it is impossible completely to separate the narratives guiding individuals and communities in the execution of the practical tasks from the practices themselves since there is and there must be an intrinsic relationship between these two elements. Thus, an individual for MacIntyre seems to be tightly enmeshed, encumbered or caught into this inextricable network of practical and narrative activities which sustain his community and himself with it, often aware of the extent to which it is so.

MacIntyre argues that human being, in so far as it is human, always belongs to a community. We are becoming a part of a community by mastering its language which is our first first language. We become members of another community through mastering its language which then becomes our second first language. Together with language, we are entering the world of narratives typical to a given community which are the source of self-identification of its members and of the community as a whole. We are also entering a set of practices, that is organised human activities, which are directed towards particular goals, whose attaining is a permanent aim of the community's existence in the first place. Practices and narratives are the chief constituents of a tradition of the community: the tradition is perpetuated by the very existence of the community, and vice-versa; the community is the carrier of the tradition, the tradition is the guide of the community.

Along with the set of practices, narratives and stories typical to a particular tradition, every one of us is adopting a way of understanding things particular to that tradition. Every type of such an inquiry is not, and cannot be, absolutely objective, rational, or unbiased. Every inquiry is constituted by a tradition and contributes to that tradition by continuously constituting it ever anew. This tradition-constituted and tradition-constitutive inquiry is a basis for our practical judgements and valuations and is fundamentally affected by them. It also follows that there is no one set of political institutions which would be universally applicable and universally effective. Thus, every tradition generates its own standards of rationality. For this reason, it does not make sense to say that there is just one rationality. Indeed, there are as many rationalities as there are traditions, and they historically evolve together with the community and within an internal argument that keeps the community and its tradition alive.

${ }^{19}$ A. MacIntyre, After Virtue: A Study in Moral Theory, Notre Dame 1984, p. 220. 
I am born with the past; and to try to cut off myself from that past, in the individualist mode, is to deform my present relationships. [...] What I am, therefore, is in key part what I inherit, a specific past that is present to some degree in my present, I find myself part of a history and that is generally to say, whether I like it or not, whether I recognise it or not, one of the bearers of a tradition. ${ }^{20}$

In other words, the task of the individual is to afford the recognition not to other individuals within a given community but to the values and norms embodied and embedded within the tradition to which she belongs. In other words, the thus understood recognition applies not to other individuals but to the values and norms constituting the tradition. It is also worth stressing that the norms and values in this context constitute not an "abstract" horizon of ethics, as in Honneth, but concrete moral injunctions developed within a tradition. Adopting a similar approach, Charles Taylor undertook a vast project of locating the sources of the atomistically understood self. He claims that it has beginnings in the works of John Locke.

The subject of disengagement and rational control has become a familiar modern figure. One might almost say it has become one way of construing ourselves, which we find it hard to shake off. It is one aspect of our inescapable contemporary sense of inwardness. As it develops to its full form through Locke and the Enlightenment thinkers he influenced, it becomes what I want to call the "punctual" self. ${ }^{21}$

Taking as his starting point the assertion that a man is a self-interpreting animal, Taylor goes on to say that the self-interpretation is a process which is constitutive for the emergence of us as separate individuals. But at the same time, he claims that we could never become individuals had it not been for the social environment in which this self-interpretation is taking place and which provides us with the necessary tools for engaging in this process in the first place. For our sense of identity is not something which we can construct entirely on our own; it is bound to have a strong social dimension since the construction of the self is done within and by means of the language and, as Wittgenstein argued, the language is something which can never be private, i.e., cannot be created individually: it is necessarily social and intersubjective. Thus, our identity is a dialogical product of our interactions with other people who share with us our language. The shared language is also a means through which we are endowed in this dialogical process with capabilities of moral evaluation, and, more significantly, of "strong" moral evaluation, ${ }^{22}$ which Taylor understands as appealing to something beyond the agent himself; our strong evaluations are strong in virtue of the fact they invoke not our internal emotions, likings or dislikings, but standards external to us which point to the judgements which defy the emotivist ideas of morality. The concept of strong evaluation is for Taylor integral to the selfhood, for he understands the self as being constituted in a significant part by the process of strong evaluations which connect us in well-defined ways with other people. Almost all our strong evaluations are prior to us and we inherit them from the others. Also, he claims,

20 Ibid., p. 220.

21 Ch. Taylor, Sources of the Self: The Making of the Modern Identity, Cambridge 1989, p. 160.

22 Ch. Taylor, "Self-Interpreting Animals," [in:] Ch. Taylor, Human Agency and Language: Philosophical Papers, vol. 1, Cambridge 1985, p. 65. 
we have no choice but rely on them and to allow them to guide us in something which we superficially take as our own "private," independent choices. Thus, our sense of who we are cannot be determined without a reference to our extra-individual commitments and identifications. The intersubjectively defined meanings of the terms in which we describe ourselves - as sons, daughters, mothers, fathers, employees - are responsible for our own self-understandings as individuals. Our sense of who we are is to a large extent a function of that what others take us to be, and the image of ourselves created by others is reflected back to us by the individuals and groups with whom we are dealing on the everyday basis. ${ }^{23}$ Once again, standards of evaluations and strong evaluations, just as meanings of linguistic expressions, are subject to recognition as something that cannot be reduced to acts of approval or disapproval by any individual.

This approach toward the individual has for Taylor important political consequences; he describes his own position as a "holistic individualism." 24 This seemingly contradictory stance can better be understood by looking at it through his distinction between ontological and the advocacy of issues in the communitarian-liberal debate. On the ontological level, Taylor is a strong communitarian, but on the level of the ideological issues he does not wish to forsake the liberal ideas of freedom and individual differences. He criticizes the modern democracy as based on the liberal atomism, and strives to reformulate the liberal arrangements in such a way as to allow for the reasonable level of political participation which is to reflect social diversity, and at the same time to endow the democratic politics with a genuine sense of belonging to a community.

The individualist methodological approach is subject of criticism not only of the communitarian antimodernist thinkers but also of the so-called postmodernists. The subject, the nodal point of the 18th-century post-Cartesian epistemology and morality, is being deconstructed and dislodged from its dominant position. The excesses of individualism, especially rationalism and the postulate of the blind rule-following which he saw as a result of the Enlightenment's concept of morality were subject of criticism by Zygmunt Bauman who held it responsible for all evils of the modern European civilisation, including the atrocities of the communism, the Nazi ideology and the Holocaust. ${ }^{25}$ In order to reject the Enlightenment's stifling ethical code, he suggested, we should again to become moral, i.e., to personalize the morality and to salvage it from the rationalistic pretensions of 18th-century thinkers. According to Bauman, there seem to exist some natural, autonomous state of morality, unadulterated by any artificial ethical (scil. rational) universal rules. Bauman saw ethics as a set of rules imposed on the spontaneously emerging moralities of different communities. ${ }^{26}$ In this, he echoed Hegel's distinction between Sittlichkeit and Moralität, the former being the result of the

${ }^{23}$ Cf. J. Horton, "Charles Taylor: Selfhood, Community and Democracy," [in:] Liberal Democracy and its Critics, A. Carter, G. Stokes (eds.), Cambridge 1988, pp. 158-159.

${ }^{24}$ Ch. Taylor, "Cross-Purposes: the Liberal-Communitarian Debate," [in:] Ch. Taylor, Philosophical Arguments, Cambridge 1995, p. 301.

25 Z. Bauman, Modernity and the Holocaust, Cambridge 1989.

26 Z. Bauman, Postmodern Ethics, Cambridge 1993, esp. pp. 16-36, 223-250. 
natural development of morals and customs obeyed by the communities, the latter being the product of the rationalist philosophers, especially Kant who attempted to impose universal rules of conduct on the living moral network. More importantly, following Emmanuel Levinas ${ }^{27}$ and Knud E. Løgstrup, ${ }^{28}$ he had built an opposition between the rule-based ethic and morality of responsibility, and rejected the former in favour of the latter.

The most important consequence of the debate between liberals and communitarians seems to be nearly universal agreement in rejection of the Enlightenment's priority of epistemology over social philosophy. The rejection is tantamount to a repudiation of something which may be called the "cognitivist fallacy," i.e., a conviction according to which knowledge is a necessary precondition of morality. The sentiment has been expressed, among others, by Richard Rorty who claimed that solidarity is more important than objectivity, and that democracy, in order to function, does not need epistemological justification or metaphysical grounding. ${ }^{29}$ A justification for principles of social action is thus to be sought within the sphere of morals and values, not the theory of knowledge.

\section{A Scottish Exception}

The individualist vision of the social world is attributed to the thinkers of the Enlightenment. In the light of the above, this judgement finds an ample confirmation in the work of many writers of the period, though its beginning should rather be sought in the period of Renaissance dominated by the intellectual order within which the concept of the individual played a crucial role; during the Enlightenment the individualist view of the society was supported in particular by an individualist conception of rationality. Thus, one may say that at least some of the Enlightenment thinkers stand guilty as charged. But there were exceptions to this, David Hume being the most important of them. Hume appears to have escaped both horns of the dilemma between individualism and collectivism. According to Maclntyre, the source of the present moral predicament is the failure of Kantian and post-Kantian moral philosophies to defend a secular rationalist moral philosophy from Hume's attack on rationalism. Like Annette Baier, I disagree with that assessment of Hume's contribution to moral theory. ${ }^{30}$ Moreover, I believe that MacIntyre's criticism of the Enlightenment project as a whole prevented him from appreciating significant affinities between the work of Hume and his own. ${ }^{31}$

${ }^{27}$ E. Levinas, Ethics and Infinity: Conversations with Philippe Nemo, trans. R.A. Cohen, Pittsburgh 1982, pp. 95-101; cf. Z. Bauman, Modernity and the Holocaust, p. 183.

${ }^{28}$ K.E. Løgstrup, "Pligt eller ansvar" [Duty or Responsibility], transl. H. Fink, R. Stern, Kirken og Tiden 14 (1938), p. 214.

${ }^{29}$ R. Rorty, "The Priority of Democracy to Philosophy," [in:] R. Rorty, Objectivity, Relativism, and Truth, Cambridge 1991, pp. 173-196.

${ }^{30}$ A. Baier, Postures of the Mind: Essays on Mind and Morals, Minneapolis 1985, p. 233, 236.

31 Some affinities between MacIntyrean and Humean approaches have been enumerated in A. Baier, "Civilizing Practices," [in:] A. Baier, Postures of the Mind, pp. 247-262, where she also points out the ideological reasons behind MacIntyre's critical view of Hume. 
The uniqueness of Hume's moral thought may be appreciated especially through the contrast between his work and Kant's, whose critical powers, supposedly, in his own words, were awaken by the Scottish moralist. A closer reading of Hume justifies Bertrand Russell's opinion, according to which Kant was indeed woken up from his dogmatic slumber by David Hume, but only to fall back into it again. It seems that Hume's work may serve as a guide leading to the way out from the entrapment between excessively abstract and rationalist individualism and the equally excessively anti-rationalist and collectivist communitarianism. ${ }^{32}$

The conviction is based on Hume's consistent sceptical attitude toward the legislative and law-giving abilities of the philosophical reason, so often seen in the thinkers of the Enlightenment. For Hume, "nothing is more requisite for a true philosopher, than to restrain the intemperate desire of searching into causes, and having establish'd any doctrine upon a sufficient number of experiments, rest contented with that, when he sees a farther examination would lead him into obscure and uncertain speculations." ${ }^{33}$ He stresses instead that the "true philosophy approaches nearer to the sentiments of the vulgar, than to those of a mistaken knowledge." ${ }^{34}$ Especially in his moral philosophy Hume attributes to "the vulgar," as well as to the customs and habits, the infallibility which cannot be achieved through the abstracted philosophical speculations of the pure reason. In his extended argument against Locke's concept of the original contract, having first provided logical and historical evidence against it, he subsequently had a recourse to a very specific authority to support his deliberations. This authority is nothing other than that of the "universal consent of mankind," of the "popular authority," or of "the sentiments of the rabble." Juxtaposing these "sentiments of the rabble to any philosophical reasoning," Hume formulates quite a remarkable claim that "it must be observ'd, that the opinions of men, in this case, carry with them a peculiar authority, and are, in a great measure, infallible." 35 The infallibility of the opinions of men is for Hume an antidote to the judgements which can follow from a "too strict adherence to a system in philosophy." ment which could possibly be attributed to an inadvertent error. For further down in the Treatise he repeats that "[t]he general opinion of mankind has some authority in all cases; but in this of morals is perfectly infallible. Nor is it less infallible, because men cannot distinctly explain the principles, on which it is founded." 37

Hume's moderate expectations from, and the sceptical attitude towards, the authority of philosophy result largely from his view of human reason as intimately connected with volitions and passions. Reason as understood by Hume can never influence any of our actions; it is completely passive or "perfectly inert." "38 All it can

32 The argument that follows owes much to the interpretation of Hume by Annette Baier, especially in her Moral Prejudices: Essays on Ethics, Cambridge 1994.

33 D. Hume, Treatise on Human Nature, Oxford 1896, p. 13.

34 Ibid., p. 223.

35 Ibid., p. 546.

36 Ibid., p. 547.

37 Ibid., p. 552.

38 Ibid., pp. 457-458. 
do is to direct our judgement in our search for causes and effects. ${ }^{39}$ But at the same reason is constantly exposed to the influences of our emotions, feelings and will. For example, if we have a prospect of pain or pleasure to be caused by some object, we experience emotions of attraction or aversion, and act accordingly. As Hume's analysis of this example shows, the reasoning is confined to the discovery of the relationship between the types of objects and the character of their influence on us. But at the same he stresses that the impulse to act accordingly to the formed expectations arises not from reason but it is only directed by it. This leads him to conclude that reason is nothing but the discovery of the connections between objects and their effect upon us. Thus, reason can never produce any action nor give a rise to any volitions, and, equally, it cannot prevent us from experiencing any volitions. Hume concludes that reason has no original influence on its own on our actions nor can it withstand any influences of the will. In the famous passage he asserts:

Thus it appears, that the principle, which opposes our passion, cannot be the same with reason, and is only call'd so in an improper sense. We speak not strictly and philosophically when we talk of the combat of passions and of reason. Reason is, and ought only to be the slave of the passions, and can never pretend to any other office that to serve and obey them. ${ }^{40}$

Sceptically withholding his judgement concerning the existence of the substance and the cause, Hume adopted similar attitude towards the existence of human soul, the site in which human reason was believed to reside. His approach toward the individual, rendering the personal identity as fluid, prefigures much later philosophical attempts towards the deconstruction of the substantive human self. He writes, for example:

When we talk of self or substance, we must have an idea annex'd to these terms, otherwise they are altogether unintelligible. Every idea is deriv'd from preceding impressions; and we have no impression of self or substance, as something simple and individual. We have, therefore, no idea of them in that sense. ${ }^{41}$

And he continues: "When I turn my reflexion on myself, I never can perceive this self without some one or more perceptions; nor can I ever perceive any thing but the perceptions. 'Tis the composition of these, therefore, which forms the self." 42

This is how Hume understands the fluidity of the self within his naturalistically oriented epistemology. But it also has an immediate effect upon his conception of the self within his moral philosophy, leading him to something which can be described as an ethnocentric or even a communitarian concept of morals. The best way to understand this aspect of his moral philosophy is to look at his definition of sympathy as "the most remarkable quality of human nature," allowing us to "sympathise with others, and to receive by communication their inclinations and

\footnotetext{
39 Ibid., p. 414.

40 Ibid., p. 415.

41 Ibid., p. 633.

42 Ibid., p. 634.
} 
sentiments, however different from, or even contrary to our own." 43 This feature of human nature is to be found not only in the children, who easily embrace every opinion that is proposed to them, but also

in men of the greatest judgement and understanding, who find difficult to follow their own reason or inclination, in opposition to that of their friends and daily companions. To this principle we ought to ascribe the great uniformity we may observe in the humours and turn of thinking of those of the same nation; and this is much more probable that this resemblance arises from sympathy, than from any influence of the soil and climate [...]. ${ }^{44}$

These considerations lead Hume to formulate very modern, or rather "post-modern" idea of the social construction of the human being as a creature whose most fundamental feelings and features do not originate in him or her in virtue of some natural endowment, but rather they are inscribed into the individual through the process of the social interaction with others, in which sympathy plays the fundamental role. "Hatred, resentment, esteem, love, courage, mirth and melancholy; all these passions I feel more from communication than from my own natural temper and disposition." 45 Just like Hume's criticism of the substantive self prefigures in some ways much later deconstruction of the allegedly impenetrable atomic self, his concepts of communication and sympathy, being crucial in the social construction of the self, prefigures the communitarian criticism of individualism in the sense that it stresses the commonality of an individual's moral features and the fact that they are to a significant degree formed in each individual through his or her participation in the communicative processes with others. Especially the idea of communication makes Hume's concept of the individual resemble MacIntyre's conception of the narrative sources of the self and Taylor's view of human beings as self-interpreting animals. ${ }^{46}$ Significantly, both these authors invoke the concept of conversation which they seem to understand somewhat like Hume understands his idea of communication. In order to make his point, Taylor introduces the distinction between the matters which are for me and/or you, and the matters which are for us. This can be explained with the help of an example of two neighbours working in their gardens in the back of their houses. At some point, one of them breaks up the silent work and says: "Fine weather we are having." As Taylor notices, the conversation opener does not provide the other neighbour with an important information of which he would previously be ignorant. He is working in his garden just because he is consciously taking advantage of the aforesaid fine weather. What the trivial remark achieves is the fact that the weather, being formerly a matter for each neighbour separately, from now of becomes a matter to both of them. This attending-together-to-something is not reducible to attending to the same thing in the separation of our loneliness. Thus, the conversation "is not the co-ordination of actions of different individuals, but a common action in this strong, irreducible sense; it is our action." "This threshold, which conversation takes us over, is one that matters in all sorts of ways and on all sorts

\footnotetext{
43 Ibid., p. 316.

44 Ibid., p. 316-317.

45 Ibid., p. 317.

${ }^{46}$ Ch. Taylor, "Self-Interpreting Animals," pp. 45-76.
} 
of levels in human life. In human terms, we stand on a very different footing when we start talking [...]." ${ }^{\prime 4}$ It is precisely this view of the communication and sympathy, through which individuals create and understand themselves and each other, which makes Humean moral philosophy markedly different from the egoistic conceptions of many other Enlightenment philosophers.

The difference can be further appreciated by having a look upon his reflections on the most important human passions, that of friendship and love. In his autobiographical essay My Own Life, Hume confesses that he took pleasure in the company of modest women and that he had no reason to be displeased with reception he was met with from them. ${ }^{48}$ Humean view of the intrinsically societal nature of human beings, their morality and their passions, is in a telling contrast with Kant's moral philosophy. There is no evidence of Kant's involvement in similar relationships. For this reason, Baier called him a misamorist. ${ }^{49}$ But she also argued that this difference is not only one of the individual inclinations of both philosophers; for it makes its way to their conceptions of morality. This issue highlights still another aspect of the contrast between Kantian monadic and contractualist view of human relationships and Hume's concept of man as a natural creature and dependent upon contingent social relations.

Kant stresses that true friendship is merely an ideal. He approvingly quotes the Greek saying, attributed by him once to Socrates and, on another occasion to Aristotle: "My dear friends, there are no friends." Kant acknowledges that

we all have a strong impulse to disclose ourselves, and to enter wholly into fellowship; and such self-revelation is further a human necessity for the correction of our judgement. To have a friend whom we know to be frank and loving, neither false nor spiteful, is to have one who will help us to correct our judgement when it is mistaken. This is the whole end of man, through which he can enjoy his existence. But even between the closest and most intimate friends there are still some things that call for reserve. ${ }^{50}$

Interestingly, this Kantian remark points out to the distinction between the private and intimate spaces which are usually conflated in today's social and political philosophy. Although he recommends a prudent and carefully measured "disclosure" between friends, at the same time he warns the lovers from too intimate relationships with one another by saying that an intimate can be "capable of sending us to the gallows in a moment of passion, though he would implore our pardon as soon as he had cooled down." Kant evidently thought that the duty of respect and keeping a due distance from an another is much more important than a loving and intimate tie. Annette Baier commented upon it that for Kant "the whole end of man is correct judgement, not fellowship. Fellowship is merely a means to this end, and a risky one." ${ }^{51}$ Or rather, more likely, he was just afraid of too close a relationship.

47 Ch. Taylor, "Cross-Purposes: Liberal-Communitarian Debate," [in:] Ch. Taylor, Philosophical Arguments, Cambridge 1995, pp. 189-190.

48 D. Hume, Essays, Moral, Political and Literary, E.F. Miller (ed.), Indianapolis 1985, pp. xl-xli.

49 A. Baier, Moral Prejudices: Essays on Ethics, Cambridge 1994.

${ }^{50}$ I. Kant, Lectures on Ethics, transl. L. Infield, New York 1963, p. 244.

51 A. Baier, Moral Prejudices, p. 34. 
In an extended argument devoted to the subject of love, Hume formulated most interesting statements concerning the nature of human individual, which, despite its social nature, still remains for Hume one of the animals:

In all creatures, that prey not upon others, and are not agitated with violent passions, there appears a remarkable desire of company, which associates them together, without any advantage they can ever propose to reap from their union. This is still more conspicuous in man, as being the creature of the universe, who has the most ardent desire of society, and is fitted for it by most advantages. We can form no wish, which has no reference to society. A perfect solitude is, perhaps, the greatest punishment we can suffer. Every pleasure languishes when enjoy'd a-part from company, and every pain becomes more cruel and intolerable. Whatever other passions we may be actuated by pride, ambition, avarice, curiosity, revenge or lust; the soul or animating principle of them all is sympathy; nor would they have any force, were we to abstract entirely from the thoughts and sentiments of others. Let all the powers and elements of nature conspire to serve and obey one man: Let the sun rise and set at his command: The sea and rivers roll as he pleases, and the earth furnish spontaneously whatever may be useful or agreeable to him: He will still be miserable, till you give him some one person at least, with whom he may share his happiness and whose esteem and friendship he may enjoy. ${ }^{52}$

It is worth stressing that the appreciation and esteem of a friend who is willing to share one's happiness is one of the basic forms of positive recognition understood in an individualist manner. In an argument against philosophers who locate the source of every human feeling in man's selfishness, he similarly strives to undermine the idea that since every act of virtue or friendship is accompanied by a secret pleasure, these passions cannot be disinterested. "The virtuous sentiment or passion produces the pleasure, and does not arise from it. I feel pleasure in doing good to my friend, because I love him; but do not love him for the sake of that pleasure." ${ }^{\prime 53}$

To sum up the difference between Kant and Hume, we may, following Baier, say that where Kant pronounces a warning to the effect that we should not treat our friends in a way we might regret when they cease to be our friends, Hume offers a radically opposing injunction: do not treat strangers in ways you will regret should they become your friends. ${ }^{54}$ For "[o] ur situation, with regard both to persons and things, is in continual fluctuation; and a man, that lies at a distance from us, may, in a little time, become a familiar acquaintance." ${ }^{\prime 55}$

As we have seen, Hume denies the reason its ability to control and direct our actions. "To consider the matter aright, reason is nothing but a wonderful and unintelligible instinct in our soul, which carries us along a certain train of ideas, and endows them with particular qualities, according to their particular situations and relations. ${ }^{\prime 56}$ By thus making it contingent upon our circumstances, volitions and passions, human reason seems to become incapacitated and cannot perform its purported directive and supervisory role of our actions which was ascribed to it ever since Socrates. It would seem, then, that by Hume's doing so, all moral philosophy collapses, because, after all, its overall aim - to provide rational direc-

\footnotetext{
${ }^{52}$ D. Hume, Treatise, p. 363.

53 D. Hume, Essays, pp. 85-86.

54 A. Baier, Moral Prejudices, p. 40.

${ }^{55}$ D. Hume, Treatise, p. 581.

56 Ibid., p. 179.
} 
tions in our behaviour - cannot be achieved on the basis of a view of reason which cannot be our moral guide anymore. But even if we follow Hume in depriving human reason of these controlling abilities, we cannot deny that there are rules of conduct which we look up to in performing our actions. It is understandable, then, that many philosophers, like Kant, had had a recourse to the idea of universality of moral rules which serve as our unquestionable guidance in practical life. As Baier argued, ever since moral philosophers resemble scientists who "seem eternally optimistic that there is some order there to be discerned and contemplated, that such an order-seeking being as a human being must be part of a universe exhibiting the order for which it yearns." ${ }^{25}$ The question arises how, with the claims of universal reason viewed with suspicion and undermined, these rules are to be understood? This question can be asked, and profitably so, within the perspective provided by Hume.

The problem with the universalistic approach in moral philosophy is that it conceives of reason as some supra-natural element, something not from this natural world, but from a transcendent, or indeed from the transcendental realm, in which most of the humans, excepting philosophers, may partake, if at all, only to a limited degree. In opposition to this, the Humean account of the principles of morality is both naturalistic and anti-rationalist. He outlines a platform for understanding the moral rules not as dictates of the universal reason, but as something which I propose hereby to call "contingently permanent rules." By this I mean the rules which (a) are social and historical construction, (b) remain flexible and allow for a scope for variation and divergence, yet (c) do perform their controlling, regulating and ordering function.

First of all, Hume believed that the principles of morality cannot be explained only by human capability to emulate an example given to us by others nor by habit. An explanation of the principles has to refer to something he calls the natural endowment of human beings. In other words, both emulative capability and habits also have to be explained. The explanation needed he found in the concept of the sense of common interest:

This instinct, 'tis true, arises from past observation and experience; but can any one give the ultimate reason, why past experience and observation produces such an effect, any more that why nature alone shou'd produce it? Nature may certainly produce whatever can arise from habit: Nay, habit is nothing but one of the principles of nature, and derives all its force from that origin. ${ }^{58}$

Naturalism of Hume's philosophy morals is thus grounded in his belief that nature has endowed humans with a sense of common interest which acts as a guiding principle in human conduct. He wrote:

If the sense of common interest were not our original motive for obedience, I wou'd fain ask, what other principle is there in human nature capable of subduing the natural ambition of men, and forcing them to such submission. Imitation and custom are not sufficient. For the question still recurs, what motive first produces those instances of submission, which we imitate, and that train of actions, which produces the custom? There evidently is no other principle than common interest. ${ }^{59}$

\footnotetext{
57 A. Baier, Postures of the Mind, p. 233.

58 Ibid., p. 179.

${ }^{59}$ D. Hume, Treatise, p. 553.
} 
In view of Hume's naturalism in understanding the origin of moral rules, the above characterisation of them as social and historical construction may be seen as inconsistent. The inconsistency is, however, only an apparent one, which may be explained by means of the second concept of recognition introduced above. It is true that the custom and imitation themselves would be incapable of constraining the natural ambitions of the individuals, and would not be able to establish the principles of morality. That is why Hume claims that moral principles have their source in the recognition of the common interest which surpasses individual desires and ambitions. As Hoy stressed:

justice and injustice, Hume believes, have two different foundations. One is the interest men have in realizing that it is impossible to live in society without certain rules. But a second foundation is the morality in the observance of these rules which follow naturally; a recognition of their benefit to society and their public utility. Hume's view that principles of justice are the product of human conventions, then, is not a departure from his concept of natural sentiments as a basis for moral judgments. ${ }^{60}$

From the point of view of Hume's conception of human rationality, then, the universal moral rules capable of regulating our conduct are plainly impossible. The other aspect of this claim is that an insistence on postulating them is a result of a failure to recognize their true nature. The anti-rationalist aspect of his moral theory may be expressed in the following way: rational moral rules which we obey and are supposed to obey are just bundles our natural interests, passions, emotions and feelings which, through the social interaction, have crystallised into customs and habits, and which thereby acquired durability or permanence which is denied to the momentarily experienced, numerically different individual feelings and emotions. According to Hume, then, our passions ossify, crystallize or petrify into rational principles of conduct, or commandments, thus into a rational ethics, just because the observance of some more or less permanent and more or less reliable rules of conduct is a prerequisite of our being able to move effectively and safely among the objects of the natural world and other human beings. It is due to their practical effectiveness that some of our interests, needs and passions become less transient and turn into the semi-permanent sign-posts, or rather wheel-ruts, to be followed in our daily moral traffic. In virtue of their being solidified, crystallised or ossified, they differ from the individual emotions, but they also differ from the purported universally valid commandments of reason. Therein lies the difference between various rules formulated by different communities in order to regulate the processes of the satisfaction of hunger, the need of shelter and of sexual needs etc., and the particular instances of consumption, house-construction or incidents of love-making which we are all occasionally involved into. It is this difference that endows moral rules thus established with their moral force. It is also this difference which is the source of the continuous dialectics between the individual self and the community in which he is trying to make his living, and to make his life meaningful.

60 T. Hoy, Toward a Naturalistic Political Theory: Aristotle, Hume, Dewey, Rvolutionary Biology, and Deep Ecology, Westport 2000, pp. 34-35. 


\section{Bibliography}

Aristotle, Politics, transl. E. Barker, Oxford 1948.

Baier A., Postures of the Mind: Essays on Mind and Morals, Minneapolis 1985.

Baier A., Moral Prejudices: Essays on Ethics, Cambridge 1994.

Bauman Z., Modernity and the Holocaust, Cambridge 1989.

Bauman Z., Postmodern Ethics, Cambridge 1993.

Burke E., Select Works of Edmund Burke, vol. 2, Indianapolis 1999.

Honneth A., The Struggle for Recognition: Moral Grammar of Social Conflicts, transl. J. Anderson, Cambridge 1995.

Horton J., "Charles Taylor: Selfhood, Community and Democracy," [in:] Liberal Democracy and its Critics, A. Carter, G. Stokes (eds.), Cambridge 1988, pp. $155-174$.

Hoy T., Toward a Naturalistic Political Theory: Aristotle, Hume, Dewey, Revolutionary Biology, and Deep Ecology, Westport 2000.

Hume D., Essays, Moral, Political and Literary, E.F. Miller (ed.), Indianapolis 1985.

Hume D., Treatise on Human Nature, Oxford 1896.

Jennings J., "Rousseau, Social Contract and the Modern Leviathan," [in:] The Social Contract from Hobbes to Rawls, D. Boucher, P. Kelly (eds.), London-New York 1994, pp. 117-134.

Kant I., Lectures on Ethics, transl. L. Infield, New York 1963.

Leroux P., "Aux Politiques," [in:] P. Leroux, Ouvres, vol. 1, Paris 1850.

Levinas E., Ethics and Infinity: Conversations with Philippe Nemo, transl. R.A. Cohen, Pittsburgh 1982.

Locke J., Second Treatise of Government, C.B. Macpherson (ed.), Indianapolis 1980.

Løgstrup K.E., "Pligt eller ansvar" [Duty or Responsibility], transl. H. Fink, R. Stern, Kirken og Tiden 14 (1938), pp. 206-217.

MacIntyre A., After Virtue: A Study in Moral Theory, Notre Dame 1984.

Macpherson C.B., The Political Theory of Possessive Individualism: Hobbes to Locke, Oxford-New York 1962.

Rawls J., A Theory of Justice, Oxford 1971.

Rorty R., "The priority of democracy to philosophy," [in:] R. Rorty, Objectivity, Relativism, and Truth, Cambridge 1991, pp. 175-196.

Smith A., The Theory of Moral Sentiments, D.D. Raphael, A.L. MacFie (eds.), Indianapolis 1982.

Taylor Ch., "Cross-Purposes: Liberal-Communitarian Debate," [in:] Ch. Taylor, Philosophical Arguments, Cambridge 1995, pp. 181-203.

Taylor Ch., "Self-Interpreting Animals," [in:] Ch. Taylor, Human Agency and Language: Philosophical Papers, vol. 1, Cambridge 1985, pp. 45-76.

Taylor Ch., Sources of the Self: The Making of the Modern Identity, Cambridge 1989.

Taylor Ch., "What is Wrong with Negative Liberty," [in:] Ch. Taylor, Philosophy and the Human Sciences: Philosophical Papers, vol. 2, Cambridge 1985, pp. 211-229.

Watkins J.W.N., "Historical Explanations in the Social Sciences," The British Journal for the Philosophy of Science 8 (1957), pp. 104-117. 